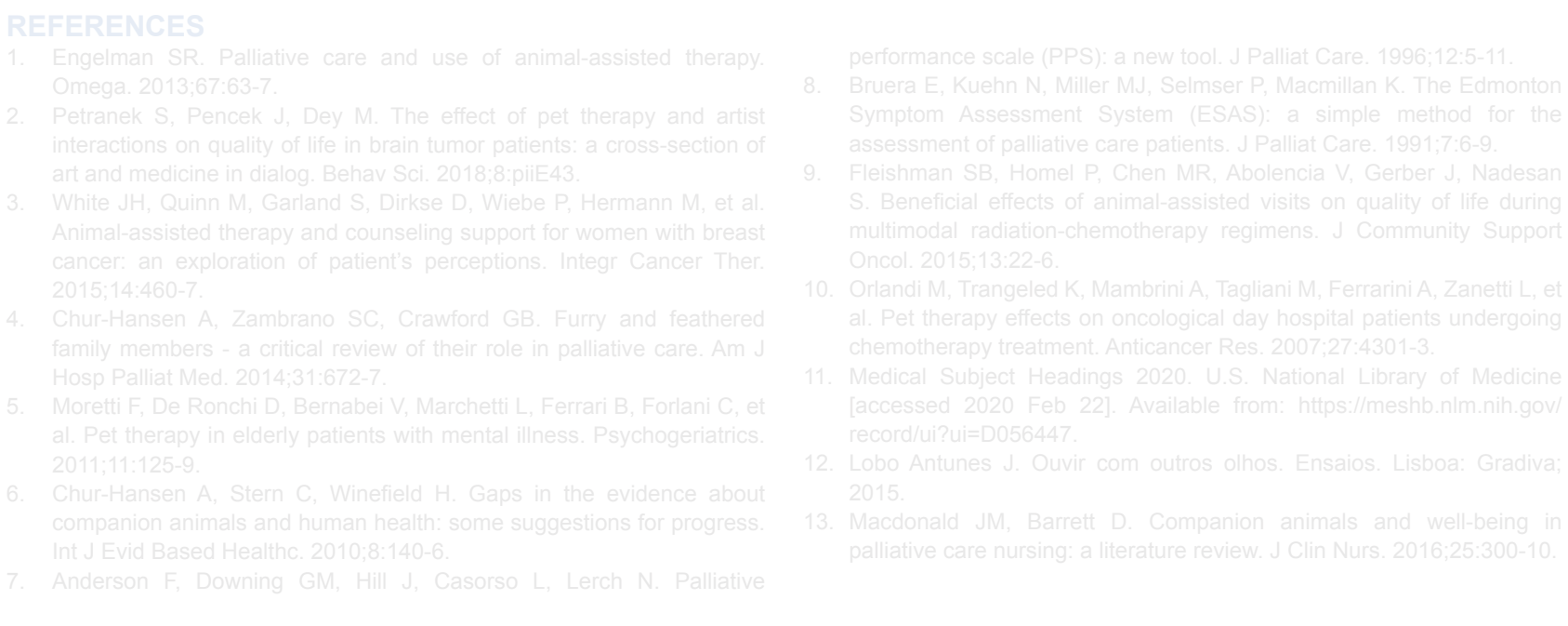

\title{
Clinical Challenges in Pedophilia-Themed Obsessive-Compulsive Disorder
}

\section{Desafios Clínicos na Perturbação Obsessivo-Compulsiva com Obsessões Pedofílicas}

\author{
Carla FERREIRA $\triangle^{1,2}$, Liliana FERREIRA ${ }^{3}$, Samuel POMBO ${ }^{1,2}$, Rui Xavier VIEIRA ${ }^{1,2}$ \\ Acta Med Port 2021 Oct;34(10):692-695 - https://doi.org/10.20344/amp.13296
}

\section{ABSTRACT}

In obsessive-compulsive disorder, pedophilia-themed obsessions-distressing intrusive thoughts about being sexually attracted to, or sexually abusing, children-are the most distressing for patients and the most misdiagnosed among healthcare professionals. Our aim is to present a case report highlighting the role stigma plays in delaying treatment, the clinical challenges in the diagnosis, and in the treatment of pedophilia-themed obsessive-compulsive disorder, in order to address the lack of literature on the subject. The case concerns a 33-year-old man with suicidal thoughts associated with the unbearable suffering caused by pedophilia-themed obsessions he had been having over the previous decade, without ever asking for help. This situation was highly disabling, leaving him mostly isolated in his bedroom. After the differential diagnosis was made, a treatment plan combining pharmacological and cognitive-behavioural therapy was implemented. After 18 months he showed a degree of remission that made it possible for him to apply for a job.

Keywords: Obsessive-Compulsive Disorder/diagnosis; Obsessive-Compulsive Disorder/therapy; Pedophilia; Social Stigma

\section{RESUMO}

Na perturbação obsessivo-compulsiva as obsessões pedofílicas - pensamentos intrusivos sobre ser sexualmente excitado, ou abusar sexualmente, de crianças - estão entre os mais angustiantes para os doentes e os mais incorretamente diagnosticados pelos profissionais de saúde. O nosso objetivo é apresentar um caso clínico destacando o papel que o estigma tem no atraso do início do tratamento e os desafios clínicos que se verificam em relação ao diagnóstico e ao tratamento desta perturbação, de modo a colmatar a falta de literatura sobre o assunto. $O$ caso é relativo a um homem de 33 anos, com ideação suicida associada ao sofrimento insuportável causado pelas obsessões sexuais pedofílicas que tinha desde há uma década, sem nunca ter recorrido a um profissional de saúde. Esta situação teve muito impacto no seu funcionamento deixando-o maioritariamente isolado no seu quarto. Após o diagnóstico diferencial, implementou-se o projeto terapêutico combinando tratamento farmacológico e psicoterapia cognitivo-comportamental. Após 18 meses o doente apresentou uma melhoria significativa permitindo-o concorrer a um emprego.

Palavras-chave: Estigma Social; Pedofilia; Perturbação Obsessivo-Compulsiva/diagnóstico; Perturbação Obsessivo-Compulsiva tratamento; Terapia Cognitivo Comportamental

\section{INTRODUCTION}

Patients with obsessive-compulsive disorders (OCD) are generally reluctant to seek treatment ${ }^{1}$ particularly if they suffer from obsessive contents involving sexually repugnant related themes such as pedophilic thoughts. ${ }^{2}$ Within sexual obsessions, pedophilia-themed obsessions, defined as excessive worries and distressing intrusive thoughts about

\footnotetext{
1. Serviço de Psiquiatria e Saúde Mental. Centro Hospitalar Universitário Lisboa Norte. Lisboa. Portugal.

2. Departamento de Psiquiatria. Faculdade de Medicina. Universidade de Lisboa. Lisboa. Portugal.

3. Serviço de Psiquiatria e Saúde Mental. Hospital Distrital de Santarém. Santarém. Portugal.

$\square$ Autor correspondente: Carla Ferreira. carla.ferreira.psiq@gmail.com

Recebido: 16 de dezembro de 2019 - Aceite: 21 abril de 2020 - First published: 24 de setembro de 2020 - Online issue published: 01 de outubro de 2021

Copyright $\odot$ Ordem dos Médicos 2021
} 
being sexually attracted to, or sexually abusing children, are amongst the most distressing given the morally repulsive contents, shame and the fear of being misinterpreted ${ }^{3-10}$ or imprisoned. ${ }^{3}$

Although there are effective pharmacological and psychotherapeutic treatments to treat $\mathrm{OCD}, 8,10$ pedophiliathemed obsessive compulsive disorder (P-OCD) requires additional clinical attention because current treatment guides tend to be written in more general terms and do not address some specific and taboo examples of OCD. ${ }^{2}$ Individuals with sexual obsessions may be considered more treatment-resistant, ${ }^{2}$ in part because P-OCD seems to be the most misunderstood and misdiagnosed symptom dimension in OCD amongst healthcare professionals, which indicates that the mental healthcare system is not providing adequate care to these patients. ${ }^{5,6}$

\section{CASE REPORT}

The case concerns a 33-year-old male, unemployed for three years and living with his father and brother, and in a 12-year relationship with his girlfriend.

When he was 29 , the patient was brought to the emergency department presenting with suicidal ideation: he couldn't cope with the pedophilia-themed obsessions that he had been having for the previous 10 years which had become worse over the previous three years, and progressively more so over the last couple of months.

He started by stating that he felt that if he stared too long at his young nephews' photos it would mean that he was a pedophile and that he could 'lose control' and act on it: he would immediately scan his body looking for bodily sensations or signs of sexual arousal, with a focus on his genital region, many times misinterpreting them, mistaking vegetative signs of anxiety (such as sweating). This took him to progressively avoid all triggering factors, such as direct contact with underage children, including his nephews, or contact through photos/tv programmes featuring children - especially when nude or wearing few clothes.
He kept mentally replaying past interactions with children and doubting whether he had become aroused or not, or acted inappropriately, when touching them or seeing them.

He frequently felt the urge to seek reassurance, from his girlfriend, that he had not written, in public places or on social media, that he was a pedophile. In recent times, he would not leave his house alone, use the computer or the telephone, leaving him secluded in his bedroom. This avoidance kept him from finishing secondary school, finding a job or socialising, ultimately leading to hopelessness and suicidal thoughts.

After the differential diagnosis was made (see the section Discussion) a combination of cognitive behavioural therapy and pharmacological treatment was implemented, in accordance with the treatment guidelines for OCD with severe functional impairment. ${ }^{8}$

The psychoeducation focused on the differentiation of pedophilia and pedophilic obsessions in OCD. The pharmacological treatment (Table 1) included a selective serotonin reuptake inhibitor, a tricyclic antidepressant, and an atypical antipsychotic; a betablocker was also added (to reduce somatic manifestations of anxiety). The cognitive restructuring focused on thought-action fusion. In exposure and response prevention, he was exposed to pictures of children, after hierarchisation of the feared situations was stated (Table 2), thus preventing him from avoiding the situation and becoming aware of the compulsions. The patient also benefited from exposure immediately after masturbation in order to confront the belief that the sensations the patient felt were not of arousal but signs of anxiety.

Despite presenting a strongly embedded stigma toward psychiatric and psychological treatment, and low insight for the disease, the patient adhered to the treatment. After 20 months of treatment, and several relapses, he was in remission: he completed a course and applied for a job. He plans to complete his secondary education soon and move in with his girlfriend.

Table 1 - Pharmacological treatment

\begin{tabular}{lll}
\hline Class & Substance & Dosis \\
\hline Selective serotonin reuptake inhibitor & Fluvoxamine & Titrated up to $350 \mathrm{mg} / \mathrm{day}$ \\
Tricyclic antidepressant & Clomipramine & Titrated up to $225 \mathrm{mg} / \mathrm{day}$ \\
Atypical antipsychotic & Risperidone & Titrated up to $6 \mathrm{mg} / \mathrm{day}$ \\
Beta-blocker & Propranolol & Titrated up to $80 \mathrm{mg} / \mathrm{day}$ \\
Benzodiazepine & Diazepam & Titrated up to $10 \mathrm{mg} / \mathrm{day}$ \\
\hline
\end{tabular}

Table 2 - Hierarchisation of the feared situations in a case of P-COD, prior exposure and response prevention

\begin{tabular}{l}
\hline Children appearing to be older 10 years of age \\
Children between $5-10$ years of age \\
Children appearing to be younger than 5 years of age \\
Children in swimsuits or undressed of all ages \\
Children appearing to be younger than 1 year of age \\
The underage cousins of the patients
\end{tabular}




\section{DISCUSSION}

A differential diagnosis should be primarily made with pedophilia: the sexual arousal derived from recurrent fantasies, sexual urges or behaviours involving prepubescent children, that could, or not, involve the sexual abuse of children. ${ }^{2}$

There are clinical distinctions between these entities ${ }^{11-14}$ : the first is the ego-dystonic and marked suffering in patients with P-OCD, contrary to most pedophiles that present pleasure when imagining sexual acts with children. Besides, they enjoy being near children and experience sexual gratification when engaging in grooming activities. ${ }^{7}$ The opposite happens in OCD patients given that they avoid all contact with children. ${ }^{2}$

For some individuals this attraction towards children is experienced with suffering and they decide not to act on it, motivated by moral values: in these cases it might be harder to differentiate ${ }^{2}$ making it essential to investigate the degree of sexual arousal experienced, the sexual fantasies, or if the individual masturbates with the mental images of children or child pornography in mind. ${ }^{2}$ In this patient none of the criteria for pedophilia were present and the diagnosis was P-OCD

This case brings to light that sexual obsessions are likely to be under-reported and under-treated, and it is clear that the treatment was delayed for so many years, impairing the patient's social, professional and personal functioning, due to the shame of having a psychiatric illness and fear of being judged, by the healthcare professional, with prejudice or ridicule.

Moreover, there is evidence that the risk of suicidal behaviour must be explored, particularly in those with symptoms in the sexual/religious dimension. ${ }^{15}$

Likewise, individuals with obsessive thoughts from different symptom dimensions might avoid the disclosure of sexual obsessions, even after disclosing other types of intrusive thoughts, because they are perceived as less acceptable: Cathey (2013) found that the disclosure of an intrusive thought relating to a sexual theme was associated with more social rejection than the disclosure of a contamination-related intrusive thought. ${ }^{3}$

Thus, it is important that healthcare providers normalise these types of concerns when interviewing OCD patients: Steinberg, ${ }^{14}$ in a study about stigmatising attitudes in clinicians, found that, when engaging with professionals with cognitive-behavioural backgrounds, participants were more likely to socially reject or be concerned about individuals with obsessions related with contamination, harming, and sexual obsessions than those with scrupulous obsessions, and that they would be less likely to reveal sexual obsessions to others if they were experiencing those rather than the other three types of obsessions.

Even though there is scarce literature published on $\mathrm{P}$ OCD, the literature does include some anecdotal cases that report serious consequences for patients caused by uninformed mental health professionals, ${ }^{2}$ including a case in which the patient was wrongfully reported to Child Protective Services; therefore, it is paramount to raise awareness, invest in better training sessions and case supervision for psychiatry residents, specialists, nurses and other mental health staff; given that many clinicians are prone to misinterpret intrusive thoughts of a sexual or aggressive nature as a desire to commit such acts. ${ }^{5}$

\section{AUTHORS CONTRIBUTION}

CF: Conception of the study, data acquisition, literature review.

LF: Literature review; critical review of the article.

SP: Conception of the study, data acquisition.

$\mathrm{RXV}$ : Conception of the study, critical review of the article.

\section{PROTECTION OF HUMANS AND ANIMALS}

The authors declare that the procedures were followed according to the regulations established by the Clinical Research and Ethics Committee and to the 2013 Helsinki Declaration of the World Medical Association.

\section{DATA CONFIDENTIALITY}

The authors declare having followed the protocols in use at their working center regarding patients' data publication.

\section{PATIENT CONSENT}

Obtained.

\section{COMPETING INTERESTS}

The authors have declared that no competing interests exist.

\section{FUNDING SOURCES}

No subsidies or grants contributed to this work.

\section{REFERENCES}

1. Belloch A, Del Valle G, Morillo C, Carrió C, Cabedo E. To seek advice or not to seek advice about the problem: the help-seeking dilemma for obsessive-compulsive disorder. Soc Psychiatry Psychiatr Epidemiol. 2009;44:257-64.

2. Bruce SL, Ching TH, Williams MT. Pedophilia-themed obsessivecompulsive disorder: assessment, differential diagnosis, and treatment with exposure and response prevention. Arch Sex Behav. 2018;47:389402.

3. Cathey AJ, Wetterneck CT. Stigma and disclosure of intrusive thoughts about sexual themes. J Obsessive Compuls Relat Disord. 2013;2:43943.

4. Gillihan SJ, Williams MT, Malcoun E, Yadin E, Foa EB. Common pitfalls in exposure and response prevention (EX/RP) for OCD. J Obsessive Compuls Relat Disord. 2012;1:251-7.

5. Glazier K, Calixte RM, Rothschild R, Pinto A. High rates of OCD symptom misidentification by mental health professionals. Ann Clin Psychiatry. 2013;25:201-9.

6. Glazier K, Swing M, McGinn LK. Half of obsessive-compulsive disorder cases misdiagnosed: vignette-based survey of primary care physicians. J Clin Psychiatry. 2015;76:e761-7.

7. Lang AR, Frenzel RR. How sex offenders lure children. Ann Sex Res. 1988;1:303-17. 
8. Nice.org.uk. National Institute for Health and Care Excellence: Obsessive-compulsive disorder and body dysmorphic disorder: treatment (Clinical Guideline CG 31). [consultado 2019 dez 01]. Disponível em: https://www.nice.org.uk/guidance/cg31.

9. O'Neil SE, Cather C, Fishel AK, Kafka M. "Not Knowing If I Was a Pedophile..."- Diagnostic questions and treatment strategies in a case of OCD. Harv Rev Psychiatry. 2005;13:186-96.

10. Pinto A, Eisen JL, Mancebo MC, Greenberg BD, Stout RL, Rasmussen SA. Taboo thoughts and doubt/checking: a refinement of the factor structure for obsessive-compulsive disorder symptoms. Psychiatry Res. 2007;151:255-8.

11. Purdon C. Cognitive-behavioral treatment of repugnant obsessions. J
Clin Psychol. 2004;60:1169-80.

12. Rosa AC, Diniz JB, Fossaluza V, Torres AR, Fontenelle LF, De Mathis AS, et al. Clinical correlates of social adjustment in patients with obsessive-compulsive disorder. J Psychiatr Res. 2012;46:1286-92.

13. Simonds LM, Thorpe SJ. Attitudes toward obsessive-compulsive disorders. Soc Psychiatry Psychiatr Epidemiol. 2003;38:331-6.

14. Steinberg DS, Wetterneck CT. OCD taboo thoughts and stigmatizing attitudes in clinicians. Community Ment Health J. 2017;53:275-80.

15. Torres AR, Ramos-Cerqueira AT, Ferrão YA, Fontenelle LF, do Rosário MC, Miguel EC. Suicidality in obsessive-compulsive disorder: prevalence and relation to symptom dimensions and comorbid conditions. J Clin Psychiatry. 2011;72:17-26. 